\title{
Ligand exchange in zirconocene dichloride-diethylzinc bimetallic systems
}

Oleg S. Mozgovoj, ${ }^{*}$ Rita N. Kadikova, Lyudmila V. Parfenova, Leonard M. Khalilov, Usein M. Dzhemilev

Institute of Petrochemistry and Catalysis of Russian Academy of Sciences, 141 Prospekt Oktyabrya, 450075, Russian Federation

* Correspondence: skill15@mail.ru; Tel.: +07-9174814769

\begin{abstract}
:
The reaction between zirconocene dichloride and excess diethylzinc in d-6-benzene solution was studied. It was found that the exchange reaction between $\mathrm{Cp}_{2} \mathrm{ZrCl}_{2}$ and $\mathrm{Et}_{2} \mathrm{Zn}$ is accompanied by the formation of such complexes as bis(cyclopentadienyl)ethylzirconium chloride $\left(\mathrm{EtZrCp}_{2} \mathrm{Cl}\right)$, a zirconium-organozinc complex, and bis(cyclopentadienyl)diethylzirconium $\left(\mathrm{Et}_{2} \mathrm{ZrCp}_{2}\right)$. It was also found that as a result of ligand exchange in zirconocene dichloride-diethylzinc bimetallic systems, the zirconium-organozinc complex is formed in minor amounts. An assessment of the thermodynamic stability of the obtained products is given based on the results of DFT analysis. The description of the NMR spectral data of the obtained organozirconium complexes is carried out.
\end{abstract}

Keywords: Zirconocene dichloride, diethylzinc, bis-(cyclopentadienyl)ethyl zirconium chloride, ligand exchange

\section{Introduction}

Chain transfer reactions between compounds of transition metals and alkyls, haloalkanes of Group II - III metals play an important role in the catalysis of homogeneous polymerization of olefins [1, 2]. A special place among chain transfer reactions is occupied by the exchange reactions of zirconocene complexes and organoaluminum compounds of various structures. Despite the low activity of these systems in polymerization reactions, they are important for organic and organometallic chemistry. $\sigma$-Ligand exchange between metallocene dichloride- and organoaluminum compounds - based systems underlies the generation of hydride and alkyl organometallic complexes initiating the reactions of hydro-, carboand cyclometalation of alkynes and alkenes. Functionally substituted products of hydrometalation and carbometalation obtained in situ are important synthons for the organometallic synthesis of various classes of organic molecules [3]. The nature of the interaction of metallocene complexes of zirconium and organoaluminum compounds has been studied in detail and continues to be studied by L.V. Parfenova with co-workers [4,5]. However, there are no literature data on the study of the exchange reactions of zirconocene complexes with organocin reagents. Currently known examples of $\mathrm{Cp}_{2} \mathrm{ZrCl}_{2}$-catalyzed 2zincoethylzincation of 5-decyne [6] and substituted 2-alkynylamines [7], as well as ethylzincation of terminal olefins [8] serve as a reliable prerequisite for the alkylation of metallocene dichlorides using diethylzinc. The results of study of the alkylation of such organozirconium complexes as bis(cyclopentadienyl)hafnium dimethyl (Cp2HfMe2, 1Me2) and [N-(2,6-diisopropylphenyl)- $\alpha$-(2isopropylphenyl)-6-(1-naphthalenyl)-2-

pyridinemethanaminato]hafnium dimethyl (2Me2) with Et2Zn are preseted in for the first time in [9]. Studying the alkyl transfer processes in the $\mathrm{Cp}_{2} \mathrm{ZrCl}_{2}-\mathrm{Et}_{2} \mathrm{Zn}$ system is an important task, since they are central to coordinative chain transfer olefin polymerization catalysis. This work presents the first results of studying the 
exchange reaction between zirconocene dichloride $\left(\mathrm{Cp}_{2} \mathrm{ZrCl}_{2}\right)$ and $\mathrm{Et}_{2} \mathrm{Zn}$.

\section{Results and discussion}

We found that the reaction of $\mathrm{Cp}_{2} \mathrm{ZrCl}_{2}$ with 4 equiv. $\mathrm{Et}_{2} \mathrm{Zn}$ in d-6benzene solution at room temperature is accompanied by the alkylation of zirconocene dichloride and the formation after $5 \mathrm{~min}$ bis-(cyclopentadienyl)ethylzirconium chloride $\left(\operatorname{EtZrCp}_{2} \mathrm{Cl}\right) \mathbf{1}$ and bimetallic species 2 in a ratio of $\sim 1: 1$ (Scheme 1).

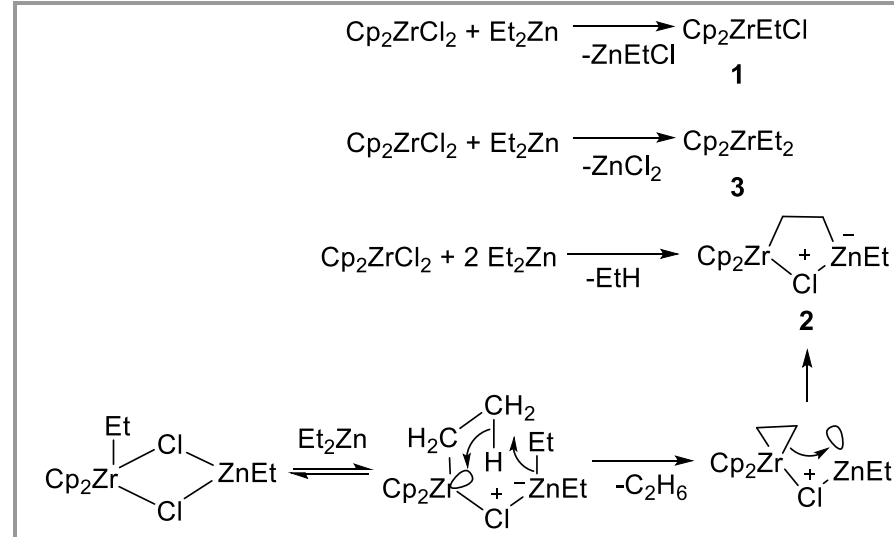

Scheme 1 Ligand exchange in zirconocene dichloride-diethylzinc bimetallic systems.

The structural identification of the obtained compounds was carried out by $1 \mathrm{D}$ and $2 \mathrm{D}$ methods of NMR spectroscopy under standard conditions. The ratio of intensities of three singlet signals of protons of cyclopentadiene rings $(\delta=5.81,5.95$, and $6.01 \mathrm{ppm})$ is equal to $1: 4: 3$, that confirms the presence of a residue of unreacted zirconocene dichloride $(\delta=6.01 \mathrm{ppm})$ and, respectively, the formation of three products as a result of the reaction ligand exchange. The presence of compound 1 in the resulting reaction mixture is indicated by the nuclear Overhauser effect, that was observed in the NOESY spectrum between the protons of the ethyl group ( $\delta=0.96-1.01 \mathrm{ppm}$ and $\delta=1.29-1.33 \mathrm{ppm},{ }^{1} \mathrm{H} \mathrm{NMR}$ ) and protons of cyclopentadiene rings $(\delta=5.81 \mathrm{ppm}$ ) (Scheme 2, Figures a) and b)). Analysis of the ${ }^{1} \mathrm{H}$ NMR spectral data shows that the signal with a chemical shift $\delta=5.95 \mathrm{ppm}$ refers to two products with different concentrations. Signals of the protons of the methylene groups in the range $\delta=0.24-0.29 \mathrm{ppm}$, as well as of the methyl group in the range of $\delta=1.22-1.25 \mathrm{ppm}$. at the ${ }^{1} \mathrm{H}$ NMR spectrum, according to the conclusions of [10], may indicate the formation of the second component of the reaction mixture bimetallic complex 2. We believe that the formation of the product 2 is result of the reaction of $\mathrm{Cp}_{2} \mathrm{ZrCl}_{2}$ with an excess of $\mathrm{Et}_{2} \mathrm{Zn}$ via bimetallic $\beta-\mathrm{C}-\mathrm{H}$ activation. The experimentally observed intense gas evolution after addition of $\mathrm{Et}_{2} \mathrm{Zn}$ to a solution of $\mathrm{Cp}_{2} \mathrm{ZrCl}_{2}$ and benzene serves as additional evidence of the formation of the complex under consideration. Spectral data for compound with a similar structure, formed as a result of the reaction of $\mathrm{Cp}_{2} \mathrm{ZrCl}_{2}$ with
$\mathrm{Et}_{3} \mathrm{Al}$, are presented in the work of Negishi [10]. The authors of [11], when they examined the interaction of $\mathrm{Cp}_{2} \mathrm{ZrCl}_{2}$ with $\mathrm{AlMe}_{3}$, note a low rate of formation of the corresponding zirconium-aluminum organic complex relative to the target product $\mathrm{Cp}_{2} \mathrm{ZrMe}$. The ratio of signal intensities at the ${ }^{1} \mathrm{H}$ NMR spectrum obtained by us also indicates the formation of bimetallic complex $\mathbf{2}$ in minor amounts. The structure of the product of complete ethylation of zirconocene dichloride 3 is identified in the ${ }^{1} \mathrm{H}$ NMR spectrum by signals of ethyl groups $(\delta=0.005-0.05 \mathrm{ppm}, \delta=0.24-0.29 \mathrm{ppm}$, and $\delta=1.22$ $1.25)$, as well as a singlet signal of protons of cyclopentadiene rings ( $\delta=5.95 \mathrm{ppm}$ ), which is equivalent to the signal of the cyclic part of the bimetallic complex 2 .

a)

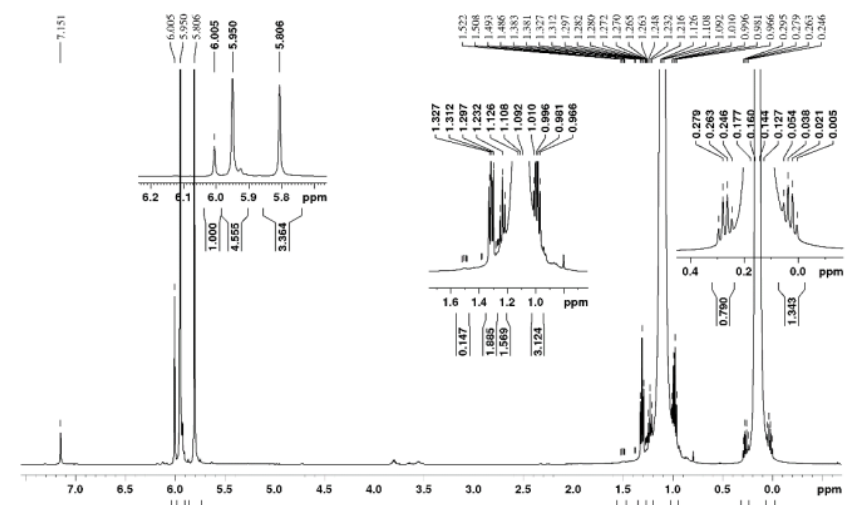

影通

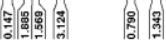

b)

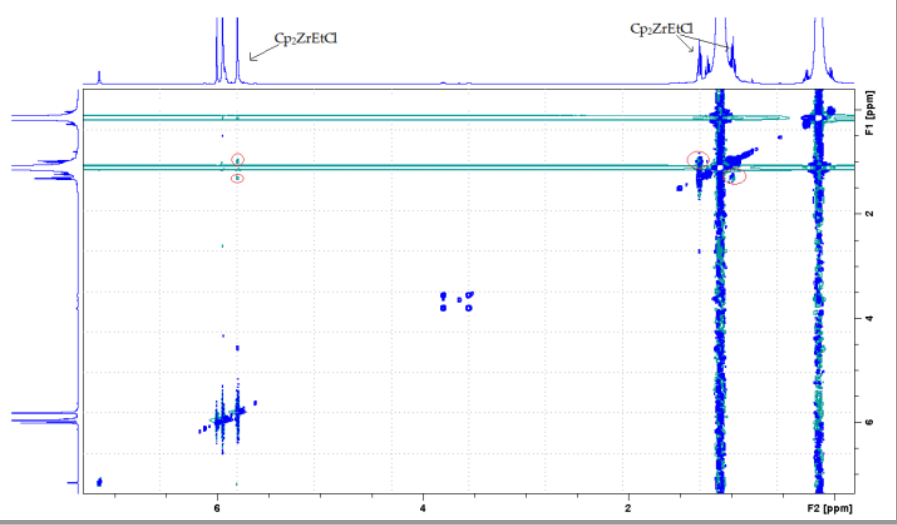

Scheme 2 (a) ${ }^{1} \mathrm{H}$ NMR spectra of a $1 / 1$ mixture of $\mathrm{Cp}_{2} \mathrm{ZrCl}_{2}$ and $\mathrm{ZnEt}_{2}$ in $\mathrm{d}-6$ benzene. (b) ${ }^{1} \mathrm{H}-{ }^{1} \mathrm{H}$ NOESY spectrum recorded at $298 \mathrm{~K}$.

The optimization of the geometric parameters of the compounds under study and the solution of the vibrational problem were carried out in the GAUSSIAN 09 program [12] within the framework of the density functional theory (DFT) using the B3LYP functional and the LANL2DZ basis set. The absence of imaginary frequencies of normal vibrations in each case indicates the thermodynamic stability of molecules 1, 2 and $\mathbf{3}$. The values of the Gibbs free energy presented in Table 1 cause the shift of thermodynamic equilibrium in the reaction system towards the reaction products. 
Table 1. Thermodynamic parameters of the compounds under study, $\mathrm{T}=298 \mathrm{~K}$

\begin{tabular}{|c|c|c|c|}
\hline № & $\begin{array}{c}(-\mathrm{G}) \\
\text { ккал/моль }\end{array}$ & $\begin{array}{c}(-\mathrm{H}) \\
\text { ккал/моль }\end{array}$ & S,кал/(моль*К) \\
\hline $\mathrm{Cp}_{2} \mathrm{ZrCl}_{2}$ & 291539,4792 & 291575,8516 & 121,9940 \\
\hline 1 & 331809,4014 & 331770,2793 & 131,2180 \\
\hline 2 & 422257,9066 & 422209,1409 & 163,5620 \\
\hline 3 & 372038,2060 & 371996,4848 & 139,9330 \\
\hline
\end{tabular}

\section{Conclusions}

Thus, as a result of our study, we have discovered for the first time ligand exchange between zirconocene dichloride and diethylzinc. It was found that the interaction of $\mathrm{Cp}_{2} \mathrm{ZrCl}_{2}$ with an excess of $\mathrm{Et}_{2} \mathrm{Zn}$ in a d-6-benzene solution leads to the formation of organometallic complexes such as bis-(cyclopentadienyl)ethylzirconium chloride $\left(\mathrm{EtZrCp}_{2} \mathrm{Cl}\right)$, zirconium-organozinc complex and bis(cyclopentadienyl)diethylzirconpium $\left(\mathrm{Et}_{2} \mathrm{ZrCp}_{2}\right)$. The ligand exchange process is accompanied by the formation of a zirconiumorganozinc complex in minor amounts. For all the compounds received, the thermodynamic stability was assessed based on the analysis of the results of the DFT study.

\section{Experimental section}

\section{General information}

All experiments were carried out under argon using Schlenk techniques. Commercially available $\mathrm{Et}_{2} \mathrm{Zn}, \geq 52 \mathrm{wt}$. $\% \mathrm{Zn}$ basis (Aldrich); bis(cyclopentadienyl)zirconium(IV) dichloride (Aldrich) and benzene- $d_{6}$, anhydrous, $\geq 99.6$ atom \% D, (Aldrich) were involved in the reactions. CAUTION: Pyrophoric nature of diethylzinc compounds requires special safety precautions in their handling. The ${ }^{1} \mathrm{H}$ and ${ }^{13} \mathrm{C}$ NMR spectra were recorded on a Bruker AVANCE500 spectrometer $\left(400.13 \mathrm{MHz}\left({ }^{1} \mathrm{H}\right), 100.62 \mathrm{MHz}(13 \mathrm{C})\right)$. As the solvents and the internal standard, benzene-d6 were employed. $1 \mathrm{D}$ and 2D NMR spectra (COSY, HSQC, HMBC, NOESY) were recorded using standard Bruker pulse sequences.

NMR Examination of the Reaction of $\mathrm{Cp}_{2} \mathrm{ZrCl}_{2}$ with 4 Equiv of $\mathrm{Et}_{2} \mathrm{Zn}$.

An argon-filled dry round-bottomed flask was charged with $\mathrm{Cp}_{2} \mathrm{ZrCl}_{2}(0.5 \mathrm{mmol}, 0,146 \mathrm{~g})$, benzene-d6 $(0.7 \mathrm{ml})$, and $\mathrm{ZnEt}_{2}$ (2 $\mathrm{mmol}, 0.2 \mathrm{ml}$ ). The mixture was stirred at room temperature for 5 min and transfer via cannula to NMR tube. NMR spectra were recorded at $298 \mathrm{~K}$. NMR examination of the reaction mixture indicated that $\mathrm{Cp}_{2} \mathrm{ZrEtCl} 1$ was formed in $83 \%$ yield: ${ }^{1} \mathrm{H}$ NMR (benzene-d6): $0.96-1.01$ (q, J = $7 \mathrm{~Hz}, J=14 \mathrm{~Hz}, 2 \mathrm{H}, \mathrm{CH}_{2}$ ), $1.29-$ $1.33\left(\mathrm{t}, \mathrm{J}=14 \mathrm{~Hz}, \mathrm{~J}=7 \mathrm{~Hz}, 3 \mathrm{H}, \mathrm{CH}_{3}\right), 5.81(\mathrm{~s}, 10 \mathrm{H}, 2 \mathrm{Cp}) .{ }^{13} \mathrm{C} \mathrm{NMR}$ (benzene-d6): $18.10\left(\mathrm{CH}_{3}\right), 48.03\left(\mathrm{CH}_{2}\right), 112.32$ (2Cp). NMR examination of the reaction mixture indicated that bimetallic species 2 was formed. ${ }^{1} \mathrm{H}$ NMR (benzene-d6): $0.24-0.29$ (q, J = 16 $\left.\mathrm{Hz}, \mathrm{J}=8 \mathrm{~Hz}, 4 \mathrm{H}, 2 \mathrm{CH}_{2}(2,3)\right), 1.22-1.25\left(\mathrm{t}, J=8 \mathrm{~Hz}, 3 \mathrm{H}, \mathrm{CH}_{3}\right), 1.48-$ $1.52\left(\mathrm{~m}, 2 \mathrm{H}, \mathrm{CH}_{2}(1)\right) 5.95(\mathrm{t}, 10 \mathrm{H}, 2 \mathrm{Cp})$. NMR examination of the reaction mixture indicated that 3 was formed. ${ }^{1} \mathrm{H}$ NMR (benzened6): $0.005-0.05$ (q, J = $16 \mathrm{~Hz}, J=8 \mathrm{~Hz}, 2 \mathrm{H}, 2 \mathrm{CH}_{3}$ ) $0.24-0.29$ (q, $J=$ $\left.16 \mathrm{~Hz}, J=8 \mathrm{~Hz}, 2 \mathrm{H}, \mathrm{CH}_{2}\right), 1.22-1.25\left(\mathrm{t}, J=8 \mathrm{~Hz}, 3 \mathrm{H}, \mathrm{CH}_{3}\right), 5.95(\mathrm{~s}$, $10 \mathrm{H}, 2 \mathrm{Cp})$.

\section{Conflicts of interest}

The authors declare no competing financial interest.

Funding: This work was financially supported by the Russian Science Foundation (grant No. 19-73-10113).

\section{Acknowledgements}

The structural studies of all compounds were performed with the use of Collective Usage Centre "Agidel" of Ufa Research of Russian Academy of Science at the Institute Petrochemistry and Catalysis (AAAA-A19-119022290004-8).

\section{References}

1. Amin, S. B.; Marks, T. J. Versatile pathways for in situ polyolefin functionalization with heteroatoms: catalytic chain transfer. Angew. Chem., Int. Ed. 2008, 47, 2006 - 2025 https://doi.org/10.1002/anie.200703310.

2. Makio, H.; Ochiai, T.; Mohri, J.; Takeda, K.; Shimazaki, T.; Usui, Y.; Matsuura, S.; Fujita, T. Synthesis of telechelic olefin polymers via catalyzed chain growth on multinuclear alkylene zinc compounds. J. Am. Chem. Soc. 2013, 135, 8177 - 8180 https://doi.org/10.1021/ja403626g.

3. Ding, A.; Guo, H. 4.15 Carbometalation and Heterometalation Reactions of Alkenes, Alkynes, and Allenes. Comprehensive Organic Synthesis (Second Edition) 2014, 4, 891 - 938. https://doi.org/10.1016/B978-0-08-097742-3.00421-3.

4. Tyumkina, T. V.; Islamov, D. N.; Parfenova, L. V.; Whitby, R. J.; Khalilov, L. M.; Dzhemilev, U. M. Mechanistic aspects of chemoand regioselectivity in $\mathrm{Cp}_{2} \mathrm{ZrCl}_{2}$-catalyzed alkene cycloalumination by $\mathrm{AlEt}_{3}$. Journal of Organometallic Chemistry 2016, 822, $135 \quad 143$. https://doi.org/10.1016/j.jorganchem.2016.08.019.

5. Parfenova, L. V.; Kovyazin, P. V.; Gabdrakhmanov, V. Z.; Istomina, G. P.; Ivchenko, P. V.; Nifant'ev, I. E.; Khalilov, L. M.; Dzhemilev, U. M. Ligand exchange processes in zirconocene dichloride-trimethylaluminum bimetallic systems and their catalytic properties in reaction with alkenes. Dalton Trans. 2018, 47, 16918 - 16937. DOI: 10.1039/c8dt04156c.

6. Negishi, E. I.; Takahashi, T. Product Class 11: Organometallic Complexes of Zirconium and Hafnium. Science of Synthesis 2003, 2, 681 - 848. DOI: 10.1055/sos-SD-002-00797.

7. Kadikova, R. N.; Ramazanov, I. R.; Gabdullin, A. M.; Mozgovoj, O. S.; Dzhemilev, U. M. Niobium- and zirconium-catalyzed reactions of substituted 2 alkynylamines with $\mathrm{Et}_{2} \mathrm{Zn}$. RSC Advances 2021, 11(8), 4631 - 4638. DOI: 10.1039/dOra10132j.

8. Gagneur, S.; Montchamp, Jean-Luc; Negishi, Ei-ichi. Ethylzincation of monosubstituted alkenes catalyzed by EtMgBr- 
$\mathrm{Cl}_{2} \mathrm{ZrCp}_{2}$ and palladium-catalyzed cross-coupling of the resultant diisoalkylzinc derivatives. Organometallics 2000, 19, 2417 2419. https://doi.org/10.1021/om991004j.

9. Luca Rocchigiani, Vincenzo Busico, Antonello Pastore, Alceo Macchioni. Comparative NMR Study on the Reactions of Hf(IV) Organometallic Complexes with $\mathrm{Al} / \mathrm{Zn}$ Alkyls. DOI: 10.1021/acs.organomet.6b00088 Organometallics 2016, 35, 9, $1241-1250$

10. Negishi, E. I.; Kondakov, D. Y.; Choueiry, D.; Kasai, K.; Takahashi, Tamotsu. Multiple Mechanistic Pathways for ZirconiumCatalyzed Carboalumination of Alkynes. Requirements for Cyclic Carbometalation Processes Involving C-H Activation. J. Am. Chem. Soc. 1996, 118, 9577 - 9588.

11. Parfenova, L.V.; Kovyazin, P.V.; Gabdrakhmanov, V.Z.; Istomina, G.P.; Ivchenko, P.V.; Nifant'ev, I.E.; Khalilov, L.M.; Dzhemilev, U.M. Ligand exchange processes in zirconocene dichloridetrimethylaluminum bimetallic systems and their catalytic properties in reaction with alkenes. Dalton Trans. 2018, 47, 16918.

12. Frisch, M. J.; Trucks, G.W.; Schlegel, H.B.; Scuseria, G.E.; Robb, M.A.; Cheeseman, J.R.; Scalmani, G.; Barone, V.; Mennucci, B.; Petersson, G. A.; Nakatsuji, H.; Caricato, M.; Li, X.; Hratchian, H.P.; Izmaylov, A.F. et. al. Gaussian 09, Revision D.01, Gaussian Inc., Wallingford CT, 2009. 